\title{
Introducing the New Lens of African Military History
}

\author{
Roy Doron \\ Winston-Salem State University \\ doronrs@wssu.edu \\ Charles G. Thomas \\ us Air Command and Staff College \\ Charles.thomas.40@us.af.mil
}

\begin{abstract}
In an effort to enrich the historical understanding of the African past, the editors of the Journal of African Military History announce the creation of a new series titled the New Lens of African Military History. In this new series, we ask for contributions that examine various aspects of the African past from a military methodology, and assess the ways that using military history helps create a more complex and complete picture of different aspects of African history. In our inaugural issue, we examine the question of genocide during the Nigerian Civil War, a hard fought war with an underdeveloped military literature. By placing the evolution of Biafra's genocide claims into the broader picture of the war, a more nuanced and complex analysis of the war and its most important legacy becomes possible.
\end{abstract}

\section{Keywords}

Biafra - genocide - New Lens - operational - editorial

We, the editors of the Journal of African Military History, were intensely proud of the span of scholarship published within our inaugural issue and felt it offered a wide variety of viewpoints and critiques of the field from a body of august and incisive scholars. While all offered us inspiration, one piece in particular, John K. Thornton's "Placing the Military in African History: a Reflec- 
tion,"1 spurred a lengthier discussion within out editorial group. The essay, which offers a reflection on what reinserting the frameworks of military history does to an African history that is often devoid of its military aspects, immediately brought to mind numerous examples within our own studies where the simple viewing of the subject through a military lens would deeply enrich the historical understanding of the African experience. Now, as a first step in promoting this continual critical reflection, the Journal of African Military History is proud to announce the creation of a new regular feature in our journal, the New Lens of African Military History. In this section, we invite and challenge scholars who work on African history to infuse military history methodologies into the study of the African past, especially in areas that have long eschewed military history and the unique lens it brings to the study of the past. We hope that these short pieces will introduce a subject and show the value of adding a military history analysis to the debate surrounding it.

Despite the fact that warfare, military life and their inevitable roles in shaping societies around the world, with few exceptions historians have largely ignored the study of military affairs in African History. In many cases, scholars have long neglected traditional "old" military history, avoiding the study of battles and warfare itself in favor of social histories of conflict. Though there are many reasons for this, the two major factors seem to be conceptual and archival. African Studies and African History began to take shape as academic disciplines in the first half of the twentieth century, mainly at Black Colleges across America. This process accelerated in the century's second half with the establishment of the African Studies Association as well as the creation of African Studies departments and centers a broad swathe of American academia, and not just the Historically Black Colleges where African Studies thrived in its early days. The expansion of the discipline coincided with the struggle for independence across the continent, and the emergence of activist scholarship in the late 1950s and 196os. Many in academia in general sought to distance themselves from military matters and those in African Studies wished to avoid scholarship that could perpetuate the notion of "broken Africa," especially considering the crisis of civil-military relations in the early years of African independence.

1 Thornton 2017. 
Historians working on the continent have done more to incorporate wars and resistance to colonialism into their work, but much of their work, especially in the second half of the twentieth century falls into the nationalist historiography spearheaded by what would become known as the Ibadan School in West Africa and championed by the University of Dar es Salaam in Eastern Africa. ${ }^{2}$ Though not unique to African History, the histories of decolonization became central to post-colonial states' attempts at nation building. The use of precolonial and colonial resistance to imperialism became an important tool in attempts to create national histories in newly independent African countries, most of which were artificial colonial creations with the different ethnic and linguistic groups sharing little commonalities other than having the same colonial masters. Thus, history became a tool in shaping the present. ${ }^{3}$

Nowhere is this problem more acute than in post-colonial African conflict, be they interstate or civil conflicts. With very few exceptions, post-colonial conflicts are largely warless wars in much of the literature. Though Southern African conflicts, such as the Rhodesian Bush War and the South African Border War have extensive military historiographies, other wars, like the EthiopianSomali Ogaden war, despite their scale and even international dimensions, have left a very small imprint in military matters. The situation is compounded when examining intrastate conflicts across much of the continent, especially in conflicts with fraught political legacies. In the fifty years since the end of the Nigerian Civil War, which cost the lives of anywhere between 500,000 and $3,000,000$, no published systematic military history of the war exists. This is the despite the countless studies that dissect in minute detail every aspect of the war, from the accusations of genocide to the war's impact on the Nigerian railway system. ${ }^{4}$ Similarly, with few notable exceptions, the literature of the genocide in Rwanda largely ignores the fact that the wholesale slaughter of the Tutsi in the country was the culmination of a prolonged series of conflicts tracing back to the colonial roots of ethnicity in the region. ${ }^{5}$

In the Nigerian case in particular, a military analysis can complicate many of the established narratives of the conflict and shed new light in understanding them. As in Rwanda, the question of genocide has been the most pressing in political and cultural circles in Nigeria, but unlike Rwanda, the question of

2 Falola and Aderinto 2010.

3 It is this lumping together of African "resistance" to colonialism as a nationalizing project that is critiqued in Mihanjo and Masebo 2017.

4 Ayoola 2013.

5 One of the few recent works that places the genocide into the political and military context is Prunier 2012. 
whether the conflict was genocidal remains a major source of contention. It is not our project here to analyze the genocide argument, but rather to show that neglect of the military aspect of the study of the Nigerian Civil War has left out a large body of evidence that can shape the debate in new ways.

\section{The Military Lens on the Nigerian Civil War}

One of the most studied aspects of the Nigerian Civil War is the conflict's origins as a failure of the First Republic, and by extension, the colonial legacy. When Nigeria became independent on October 1, 196o, it came about in a flurry of optimism that Africa's most populous country would lead the continent as a political and economic powerhouse. However, almost immediately, the federal structure, built around the three largest ethno-political groups in a regional structure, began to fray. The Northern Region, dominated by Muslim HausaFulani also dominated the federal government, even though its representative party, the Northern People's Congress (NPC), received the smallest share of the popular vote among the three major parties with 25.2 percent, but earning 134 seats in the 312 seat the House of Representatives. The Igbo dominated Eastern Region's National Council of Nigeria and the Cameroons (NCNC) garnered thirty four percent of the popular vote, but secured only eighty one seats. Similarly, the Yoruba centered Action Group (AG) with its powerbase in the Western Region received 26.1 percent and seventy-three seats, with the rest of the seats going to smaller ethnic based parties.

Over the next six years, the political parties would bitterly contest virtually every aspect of the country's governance, from local and regional elections, to the census. These contestations, rife with political intrigue, corruption and fraud, led a small group of mostly Igbo officers led by Chukwuma Kaduna Nzeogwu to stage a coup on January $15,1966 .{ }^{6}$ During that fateful night, the coup plotters killed most of the NPC leadership, including the Prime Minister Abubakar Tafawa Balewa, the Northern Premier, Ahmadu Bello, as well as their close ally, the Western Region Premier Samuel Akintola. The head of Nigeria's military, Johnson Aguyi-Ironsi, led a defense of capital and after several days, the coup plotters surrendered. Though the coup failed, it also destroyed the bulk of the Northern civilian leadership, and Ironsi became head of a military government, causing some Northern officers to accuse him of being a

6 Nzeogwu's name of Kaduna came from the city of Kaduna in the North where he was born and where his family had lived. 
secret plotter. ${ }^{7}$ To assuage their fears, he named Yakubu Gowon, a Northerner albeit a Christian, his successor as head of the military. At the end of July, the country suffered a second coup, led by Major Murtala Muhammad and a cadre of Northern officers that killed Ironsi and installed Gowon as Head of State. ${ }^{8}$ Accompanying the coup came a series of attacks perpetrated on Easterners living in the Northern Region. The exact number killed can never be properly assessed, as estimates have varied from seven thousand to fifty thousand, with many of those estimates coming from the military governor of the Eastern Region, Chukwuemeka Ojukwu. ${ }^{9}$ Regardless of the actual number killed, the massacres, which the Biafran leadership quickly dubbed a pogrom, sparked a mass exodus of Easterners of all ethnicities, from all parts of Nigeria to the Eastern Region. By most estimates, the number of internally displaced refugees exceeded two million. With most of the civilian and military leadership now decimated by two coups, the country sank further into crisis as reconciliation efforts failed. By the end of May of the following year, the Eastern Region had seceded from Nigeria and became the Republic of Biafra.

Like many post-colonial African conflicts, the Nigerian Civil War is largely remembered as an almost warless war with few major military engagements. Most treatment of the war from a military perspective cites two decisive military moments, both during the war's first year. Though Biafra declared independence on May 30 1967, the war did not begin until July of that year. After a month of military losses, which included the fall of the university city of Nsukka in northern Biafra and the successful Nigerian amphibious landing at the oil depot of Bonny along the Atlantic coast, the Biafran military crossed the River Niger at the city of Onitsha and began what has become known as the Midwest Offensive. Although the offensive failed in its objective to reach Lagos and Ibadan, it transformed the Nigerian government's aims of the conflict. No longer would this be a limited engagement that Yakubu Gowon, Nigeria's military ruler, characterized as a "police action", rather, the Nigerian military shifted to a strategy of "total war" transforming the conflict into a prolonged siege that exasperated the already precarious humanitarian conditions.

7 Madiebo 1980, 32-35.

8 Muhammad, who would lead the 2nd division during the war, would later come to power in a 1975 coup that removed Gowon, before being gunned down less than a year later in yet another coup attempt.

9 In October 1966 following the massacres, Ojukwu met with the Italian ambassador, telling him that seven thousand had died in the attacks. In January 1967 at Aburi in Ghana, Ojukwu cited ten thousand. In May, when Biafra declared independence, he tripled the number to thirty thousand and two years later in his Ahiara Declaration he raised the figure to fifty thousand. For more detail see De St. Jorre 1972, 61-62. 
The Midwest offensive was a large scale, two-month long military campaign, and once it ended in early October 1967, much of the fighting centered on Nigeria's 2nd Division's attempts to capture and control Onitsha. After several unsuccessful and costly attempts at amphibious assaults across the Niger, the Division commander, Major Murtala Muhammad, led a force from the north and successfully captured the city on March 25 1968. However, six days later Biafrans attacked and destroyed a major supply convoy at Abagana, destroying the entire convoy in a chain reaction after a fuel tanker exploded, igniting several ammunition vehicles. The Biafrans' spectacular success at Abagana led Michael Gould to claim that it was the only major battle of the entire war. ${ }^{10}$

Gould's claim is central to understanding the problem with ignoring military matters when writing about war, especially in Africa. As many scholars have noted, wars and conflicts across Africa, especially near the equator tended to have smaller engagements due to several reasons. ${ }^{11}$ The dense foliage and disease environments limited the ability of massing large troop numbers and African trypanosomiasis (sleeping sickness) traditionally eliminated the use of mounted troops, such as cavalry. In the Niger Delta both sides had even more difficulties due to the lack of naval equipment. During the amphibious landing at Bonny early in the war, the Nigerians only had one functional landing craft. Thus, contrary to Gould's assessment that it was a "strange war" is correct only if comparing it, as he does, to the Second World War. From a military analysis, the Nigerian Civil War proved to be an archetypical post-colonial African conflict.

Because the war's strategic and tactical dynamics are so understudied, the issue of genocide has been removed from the conflict itself and has become the central characteristic of an otherwise neglected war. Yet, Biafra's creation and continuous adaptation of its messaging regarding genocide was one of the central and most successful tactics of the war. This success helps explain both the memory of Biafra as a genocidal conflict and questions relating to the war's longevity. However, most studies that focus on the genocide study the idea and its legacy largely without examining the military context into which the Biafrans inject the narrative. ${ }^{12}$

From the war's onset, Ojukwu and the Biafran leadership used the 1966 massacres as a platform to develop an accusation of genocide against the Nigerian

10 Gould 2012, 3, 4 Later in the book, he describes the events of the attack, but does so using only Joe Achuzia's self-aggrandized account, without taking other sources, such as Madiebo, who was the head of the Biafran military at the time.

11 For several treatments on the issue of environment in African conflicts, see Thornton 2005, Reid 2012.

12 Several examples of this appear in Korieh 2012. 
government. Before the war, the Eastern Region's government was careful not to claim genocide, instead calling the orchestrated riots that accompanied the July 1966 coup a pogrom, to evoke the Jewish plight in Tsarist Russia. Once the region seceded and became Biafra, Ojukwu's government used the genocide accusations as a tool to internationalize the conflict and force the world to intervene in accordance with the 1948 United Nations Convention on the Prevention and Punishment of the Crime of Genocide (UNGC). The main reason for Biafra's diplomatic and public offensive was the Gowon had largely been successful in shutting Ojukwu out of global diplomacy by insisting the that conflict be treated as an internal matter. For Ojukwu, the only hope for any kind of settlement was to force the Nigerians to a negotiated settlement. However, without large scale public and diplomatic pressure, any kind of negotiation not predicated on a renunciation of secession would be extremely unlikely. ${ }^{13}$

As the Midwest offensive was collapsing, the Organization of African Unity (OAU) held its annual summit in Kinshasa, Democratic Republic of Congo from September 11-14, 1967. Before the meeting, Gowon received assurances that agenda would not include the war, and the Biafrans countered with a memorandum criticizing the fact that they could not participate as a member of the OAU. It read in part

In this connection, the remorseless slaughter by Northerners of several thousand [note that the Biafrans do not give an exact number here] unarmed Eastern Nigerians in May, July and September, 1966, was merely the worst round of a continuing genocide unleashed in Jos in 1945 and followed up in Kano in 1953 against of Eastern Nigerian origin.

However, in spite of the bitter experience of the immediate past, the Government of Eastern Nigeria hoped and tried even in the middle of the pogrom of 1966 to salvage whatever common bonds still remained in the Federation. $^{14}$

This was the first time that Biafra had publicly used the term genocide to describe the events in the Northern Region. The Biafrans this communique, sent to the OAU heads of state ahead of the summit, to be impossible to ignore and pressure the OAU to place the war on its agenda despite Nigeria's insistence to the contrary. At first, it seemed the tactic succeeded. OAU leaders agreed to send a six member Head of State consultative delegation to Nigeria in Novem-

\footnotetext{
13 Stremlau 1977, 91.

14 Kirk-Greene 1971, v. 2, 169.
} 
ber 1967 to help mediate the conflict. By the time the mission arrived in Nigeria, Biafra's military situation had worsened considerably. The Midwest Offensive had completely collapsed with the last Biafran soldiers returning across the Niger into Onitsha. On September 22, Ojukwu executed Victor Banjo, the offensive's commander, along with three other experienced officers calling them saboteurs and accusing them of attempting to overthrow him. ${ }^{15}$ The Nigerian counteroffensive also led to reprisals against the Igbo population west of the Niger. On October 7 , the Nigerians entered the city of Asaba, on the other side of the Niger from Onitsha. What followed has never been adequately established. It was either an orchestrated mass murder of Asaba's population, or a complete breakdown of military discipline. Regardless, the following three days saw Nigerian troops massacre, rape and pillage the city, with the death toll well into the thousands. ${ }^{16}$ Lastly, at the end of September the Nigerian First Division entered the Biafran capital at Enugu, with Ojukwu and the rest of the leadership barely escaping in time.

In addition, the initial urgency of the letter sent to the OAU summit had begun to wane and two of the heads of state withdrew from the delegation. In the end, the summit and delegation did little to aid the Biafran diplomatic offensive, and by the end of 1967 , the Nigerians had effectively surrounded Biafra by land and naval blockade, leaving many in the enclave with little hope of achieving a sustained independence.

In a dire military situation and a population on the brink of starvation, the Biafrans opted to increase the diplomatic offensive into a public diplomacy assault, and contracted the American-owned Swiss public relations firm Markpress to act as its mouthpiece. Their ultimate goal was to increase pressure on the world recognize the Nigerian war effort as genocidal, and through that force either an end to the war, or failing that, to bring the Nigerians to the negotiating table without renouncing secession. This strategy had a mixed reaction, as the Nigerian offensives continued unabated, but throughout the year, the Biafrans had enough success both militarily and on the diplomatic front to convince the Ojukwu to continue the fight rather than sue for peace and reincorporation.

\footnotetext{
15 One of the others was Emmanuel Ifeajuna, a well-loved commander and former high jumper who became the first African athlete to win a gold medal at a major competition, winning gold at the Commonwealth Games in Vancouver, Canada in 1954. Africans won all high jump medals there, with fellow Nigerian Nafiu Osagie winning bronze and Ugandan Patrick Etolu taking silver.

16 For a detailed account of the massacres and the city's life during the rest of the war, see Bird and Ottanelli 2017.
} 
The year began with the Nigerian offensives on Onitsha. Though ultimately the Nigerians succeeded in capturing it in March, the ensuing counteroffensive and debacle at Abagana essentially eliminated the 2nd Division as a fighting force, and it played no other role in the war other than as an occupation force. The quick elimination of the division gave the Biafrans hope that the other two divisions, the 1st Division in the northern sector under Mohammed Shuwa's command, and the 3rd Marine Commando Division, led by "the Black Scorpion" Benjamin Adekunle, could also be stopped in due course.

For the Nigerians, the fiasco in Onitsha heaped pressure on Gowon's government, as the Nigerian leader had remarked that Biafra's back would be broken by March 1968. Gowon never intended his remarks to be a deadline for ending the war, but several newspapers did, with one publishing a daily countdown to March 31, as a countdown to victory, coincidentally the date of the Abagana ambush ${ }^{17}$ Even worse, after the incident, the military situation stabilized into an uneasy stalemate, as Biafra's diplomatic offensive began to take shape. Utilizing Markpress as a "drop box," Biafran propaganda and the accompanying images of children with Kwashiorkor inundated global media outlets in the spring of 1968. The resulting public outcry pressured Western governments, especially British Prime Minister Harold Wilson's cabinet, to intervene to stop the war and end what was increasingly accepted as genocide. ${ }^{18}$ Even further, Biafra's first diplomatic recognitions came as the result of this campaign. On May 8, Gabon formally recognized Biafra, with Ivory Coast, Zambia and Tanzania following soon after. ${ }^{19}$

To address this pressure, the British-led Commonwealth sponsored a peace conference in Kampala, finally giving Ojukwu's Biafra the global recognition it craved. However, by the time the conference convened on May 23, 1968, the Nigerians had made significant gains, further crippling Biafra's war effort. The military stalemate broke when the Nigerians undertook to capture Biafra's last major port, Port Harcourt. Though Biafra controlled Port Harcourt, the Nigerians had blockaded the city with the navy, and controlled the Bonny estuary leading to the Atlantic Ocean. On April 2o, the 3rd Division undertook a major operation that culminated on May 18-24, with the Nigerians wresting control of the city. ${ }^{20}$ Thus, once the conference began, Biafra's prospects for survival had

\footnotetext{
17 Stremlau 1977, 129.

18 One of the most in depth recent works on the global perception of genocide in Biafra is Heerten 2018.

19 The only other country, and only non-African one, to recognize Biafra was Haiti, which extended recognition in March 1969, less than year before Biafra's final capitulation.

The most complete account of the conquest of the city is Alabi-Isama 2013.
} 
suffered a considerable blow, but the hopes that it garnered on the diplomatic front gave Ojukwu hope that the peace conferences would force the Nigerians into a ceasefire or that international intervention would be at hand to stop the genocide.

Though Biafran messaging pressured the UK, United States and other countries to encourage the Nigerian side to accept a more active international role, Ojukwu grossly miscalculated the value of the Kampala conference, which erupted in confrontation and met with an acrimonious end. Once the Commonwealth conference failed, the OAU undertook a mediation of its own and hosted another attempt in Addis Ababa under the auspices of Emperor Haile Selassie. Despite Ojukwu's assurances that the Addis conference would not descend to farce, the meeting ended with no agreements to end the war or alleviate the humanitarian crisis caused by Nigeria's siege. In fact, the Biafran leader billed the meeting as a "summit" thinking that Gowon would arrive, albeit reluctantly. The latter did not attend either conference. After the war, Ojukwu claimed he would have been able to end it by virtue of his superior intellect alone, stating, "If Gowon had gone to Addis, I would have been able to force him to sign a cease-fire in Africa Hall in front of the Emperor." ${ }^{21}$ However, Ojukwu left Addis Ababa without a cease-fire or assurances on humanitarian relief.

As a gesture of goodwill, Gowon halted most offensives during the peace talks, and the Nigerians made little headway, much to the chagrin of the military leaders, who wanted to end the war as quickly as possible. Adekunle did not hide his disdain for the talks, and on August 14, 1968, just before the talks were set to begin stated bluntly

I want to see no Red Cross, no Caritas, no World Council of Churches, no Pope, no missionary and no UN delegation. I want to prevent even one Ibo from having even one piece to eat before their capitulation. We shoot at everything that moves and when our troops march into the centre of Ibo territory, we shoot at everything even at things that don't move. ${ }^{22}$

For many Biafrans and their supporters these words showed that the Nigerian military had been acting with deliberate intent, which was key in UNGC's definition of genocide and thus in international law. Adekunle's words, taken with the starvation, aerial bombings and reprisal killings like that in Asaba, clearly

21 Stremlau 1977, 214.

22 Garrison 1968. 
meant that the Nigerians had been waging a genocidal war, and thus, the signatories to the treaty were obliged to act according to the convention's Article viII, which unambiguously required the signatories to take action "as they consider appropriate for the prevention and suppression of acts of genocide."23 Even American Presidential candidate Richard Nixon stated that "genocide is what is taking place right now - and starvation is the grim reaper [...] this is not the time to stand on ceremonies or to observe diplomatic niceties." ${ }^{24}$ After Nixon's election in November 1968, Biafrans hoped that once in office, he would intervene. Though Nixon personally supported Biafra, as President he could do little to act on that support. ${ }^{25}$

In October 1968, Adekunle launched a military operation to capture the remaining urban centers still in Biafran hands. He named it Operation OAU after the three largest cities, Owerri, Aba and Umuahia, the last of which had been serving as Biafra's de-facto capital since the fall of Enugu early in the war. Though Adekunle's initial advance succeeded in capturing Owerri and Aba, he failed to capture Umuahia and the Biafran counteroffensives rolled back much of the Division, and even recaptured Owerri. Adekunle's blunder led Gowon to relieve him of command in May 1969 and appoint Olusegun Obasanjo to command the Division and save it from total collapse. ${ }^{26}$

However, by the time the Biafrans stemmed Adekunle's assault, the world's attention had shifted and several Biafran missteps turned the tide on what little goodwill the besieged enclave still harbored around the world. Perhaps the most glaring of these came on May 9, 1969, when Biafran commandoes attacked an Italian oil installation on the Nigerian side of the Niger Delta, killing eleven and abducting seventeen. Ojukwu quickly sentenced the workers to death, but ultimately released them a month later after a substantial ransom had apparently been paid. ${ }^{27}$ This event caused the global tide to turn against Biafra, and even allowed the Nigerian Air Force to shoot down a Red Cross relief aircraft, and arrest and deport the Red Cross' relief coordinator, August Lindt.

Even more troubling, Biafra's messaging seemed to fray in the war's waning months. Very little archival documents survive from Biafra, and wartime shortages were so acute that Biafran officials had to constantly recycle paper, fur-

\footnotetext{
231948 United Nations Convention on the Prevention and Punishment of the Crime of Genocide.

24 "Nixon's Call for American Action on Biafra," September 9, 1968, cited in Stremlau 1977, 289 Also see Obiozor 1993.

25 Doron 2016.

26 Momoh 200o, Obasanjo 1981.

27 Doron 2014.
} 
ther eroding the archival record. However, some documents remain. One such document was a critique of radio scripts that Biafrans aired in October 1969. One script, Calling Biafrans Behind Enemy Lines, touted a pan-Africanist message and blamed Europeans for not agreeing to humanitarian aid, and urged the Biafrans living under Nigerian control to suffer along with those in Biafra. However, the authors of the critique acknowledged that those under Nigerian control were probably not suffering to the same extent as those in rebel held areas.

By the end of 1969, Shuwa's division had succeeded where Murtala Muhammad and Adekunle had failed. Shuwa's Division broke the final Biafran defenses, and with Obasanjo rescuing the Third Division from annihilation, Ojukwu fled the country on January 10, 1970, and Philip Efiong, his successor, surrendered on Radio Biafra on January 12, before flying to Lagos two days later for the formal surrender.

After the end of the war, Gowon's government and subsequent military regimes suppressed discussion on the war, opting for a conciliatory "no victors, no vanquished" approach to postwar unity. Once Nigeria transitioned to civilian rule, new expressions of Biafran nationalism emerged, with many organizations, such as the Movement for the Actualization of the Sovereign State of Biafra (MASSOB), focusing on Biafra as synonymous with Igbo nationalism, neglecting the complicated history of how Biafran nationalism morphed into an exclusively Igbo project. By incorporating military history into the shift, a more complex picture of Biafra emerges and as such, this method can definitely act as a "New Lens" in understanding the multifaceted processes involved.

\section{$3 \quad$ A Call for Reflection}

It is of course this "New Lens" that we are now asking our community of scholars to take to the wide span of African historiography in the certainty that the new facets discovered will help enrich the discipline as a whole. Whether looking at precolonial slaving conflicts as something more complex and worthy of study than simple raids, as John Thornton did in his initial essay for our journal, or restoring a warfare context around the evolution of a contested genocide, as done here, the military lens can both problematize the historical narrative but also clarify African agency and actions. As such, we are proud to be inaugurating this series and hope to feature more of these pieces looking at events in African history within the New Lens of African Military History section. 


\section{Bibliography}

Alabi-Isama, Godwin. 2013. The tragedy of victory: on-the-spot account of the NigeriaBiafra War in the Atlantic theatre. Ibadan: Spectrum Books Limited.

Ayoola, Tokunbo A. 2013. "The impact of the Nigerian Civil War on the Nigerian Railway." In Warfare, Ethnicity and National Identity in Nigeria, edited by Toyin Falola, Roy Doron and Okpeh A. Okpeh. Trenton, NJ: Africa World Press.

Bird, S. Elizabeth, and Fraser M. Ottanelli. 2017. The Asaba massacre: trauma, memory, and the Nigerian civil war. Cambridge: Cambridge University Press.

De St. Jorre, John. 1972. The brothers' war; Biafra and Nigeria. Boston: Houghton Mifflin.

Doron, Roy. 2014. "Biafra and the AGIP Oil Workers: Ransoming and the Modern Nation State in Perspective." African Economic History 42:137-156.

Doron, Roy. 2016. Foreign Policy from Candidate to President: Richard Nixon and the Lesson of Biafra. Not Even Past.

Falola, Toyin, and Saheed Aderinto. 2010. Nigeria, Nationalism, and Writing History: Boydell and Brewer.

Garrison, Lloyd. 1968. "The "Point of No Return” for the Biafrans." New York Times, 8 June.

Gould, Michael. 2012. The struggle for modern Nigeria the Biafran war, 1967-1970. London; New York: I.B. Tauris.

Heerten, Lasse. 2018. The Biafran War and postcolonial humanitarianism: spectacles of suffering. Cambridge, New York: Cambridge University Press.

Kirk-Greene, A.H.M. 1971. Crisis and conflict in Nigeria: a documentary sourcebook. London: Oxford University Press.

Korieh, Chima J., ed. 2012. The Nigeria-Biafra War: genocide and the politics of memory. Amherst, NY: Cambria Press.

Madiebo, Alexander A. 1980. The Nigerian revolution and the Biafran war. Enugu, Nigeria: Fourth Dimension Publishers.

Mihanjo, Eginald P.A.N., and Oswald Masebo. 2017. "Maji Maji War, Ngoni Warlords and Militarism in Southern Tanzania." Journal of African Military History 1 (1-2):41-71. doi: https://doi.org/10.1163/24680966-oo101004.

Momoh, H.B. 2000. The Nigerian Civil War, 1967-1970: History and Reminiscences. Ibadan: Sam Bookman Publishers.

Obasanjo, Olusegun. 1981. My Command: an account of the Nigerian Civil War, 1967-1970. London; Ibadan; Nairobi: Heinemann.

Obiozor, George A. 1993. The United States and the Nigerian Civil War: An American Dilemma in Africa 1966-1970. Lagos: Nigerian Institute of International Affairs.

Prunier, Gérard. 2012. Africa's world war: Congo, the Rwandan genocide, and the making of a continental catastrophe. New York: Oxford University Press.

Reid, Richard J. 2012. Warfare in African history. Cambridge; New York: Cambridge University Press. 
Stremlau, John. 1977. The International Politics of the Nigerian Civil War, 1967-1970. Princeton, NJ: Princeton University Press.

Thornton, John K. 2005. Warfare in Atlantic Africa, 1500-1800. London; New York: Routledge.

Thornton, John K. 2017. "Placing the Military in African History: A Reflection." Journal of African Military History 1 (1-2):112-119. doi: https://doi.org/10.1163/2468og66 -00101007. 